\title{
TOURISM AND LIFESTYLES: ANALYSIS OF CROSS-CULTURAL INTERFACE
}

Ramji SHARMA

\section{ABSTRACT}

Tourism has emerged as one of the largest industries in terms of income generation and employment opportunities around the globe. It seems that none of the settlements on earth can preserve their isolation today merely due to the influx of globalization. Tourism has been established as a striking by-product of globalization. Due to its economic upshots on foreign currency earning without actually sending any tangible products out of the boarder, almost all the countries around the globe have begun to consign a high priority to its development. However, its effects and implications appear in numerous faces and facades both with momentary and enduring bearings - some with affirmative consignments and other with negative provocations. From socio-cultural dimension, tourism appears as a vehicle of cross-cultural interface resulting socio-cultural phenomena like diffusion, integration, acculturation and assimilation. Its apparent effects can be seen in every host society with different tangs and textures. The lifestyle of the people of tourist receiving community can not remain in isolation. This study analyzes the impacts caused by the development of tourism business over the lifestyles of the people of host societies viz. catchments of Fewa Lake of Pokhara and Sarangkot of Kaski, Nepal.

KEY WORDS: Tourism mpact, Impact on lifestyle, Cross-cultural interface, Socio-cultural impact, Tourist-guest interaction.

\section{PREAMBLE}

The growing interaction and inter-penetration between the existing, relatively interdependent, social system are the most salient characteristics of the contemporary world. The world is rapidly becoming a global village. No afar islands or obscure archaic tribal 
settlements manage to preserve their isolation. The globalization has easy reaches in these settlements today. Tourism itself is a progeny of the globalization. As tourism is eagerly sought for by the developing nations as an important source of revenue, it may provoke serious disruptions and cause ultimate long-range implications on receiving societies. The general belief is that the contact and interface of people with different cultural values influence each other sometime with positive attributes and sometime with completely negative and harmful dispositions. However, those impacts can be simple or complex, significant or insignificant, momentary or enduring. Fridgen (1996) explains that social impact of tourism is the effects of tourism activity or development on the social fabric of residents of destination communities - as individuals, as families, and as members of social organizations. Similarly cultural impact is the effects of tourism activity or development on the culture of a locality or region - on its arts, artifacts, customs, rituals, architecture, and, in particular, the cohesiveness and cultural identity of the residents. In a society, behavior patterns are learned as well as developed and society expects people to act accordingly. The development and maintenance of these behaviors form the cultural bedrocks of a society.

Social and cross-cultural interactions are inherent aspects in the travel process. For millions of people, they are the main reasons for travel itself. Interaction with other people and contact with unknown culture is a kind of motivation and goal, and subsequently, an effect or an outcome. The social and cultural dimensions of tourism primarily involve the travelers, members of the host community and the providers of travel services, who may or may not be local residents. In this study, Social impacts can be thought of as changes in the lives of people who live in destination communities (host communities) which are associated with tourism activity one way or the other. Social impact of tourism basically focuses upon the result of interactions between the tourist and the host or provider. The social issues which are made focal in this study are living style, dressing style, dinning pattern, menu choice, merry-making and leisure activities. Similarly, cultural impacts can be thought of as the changes in the arts, artifacts, architecture, customs, rituals, language, music, dance, folklore, attitude towards sex, crime, 
Tourism and Lifestyle...... Sharma

drug abuse, gambling and alcoholism of people that result from tourism activity or development. However, due to the inseparable, intertwining and overlapping association between social and cultural issues, the factors in the present work have been studied discretely rather than grouping them separating into social and cultural elements distinctly.

\section{OBJECTIVE AND STUDY FRAMEWORK}

The general objective of this work was to analyze the impacts of tourists-guests interface over the lifestyles of host communities that depend more or less on tourism business. To investigate and analyze the impacts and implications of such interfaces specifically, the following nine variables were taken into consideration that happened to be the study framework for this paper.

- Living style

- Dressing style

- Menu/ cuisine choice

- Dinning pattern

- Outing frequency

- Merry-making and leisure activities

- Age factor

- Profession of indigenous people

- Social relation

- Social structure

\section{RESEARCH ZONE AND METHODOLOGY}

Tourism is the main economic resource of Pokhara and its vicinity, especially for the community at the northern catchments of Lake Fewa (called Baidam) of Pokhara and the residents near the Sarangkot Tower of Kaski, Nepal. Most of the residents in both the settlements depend, directly or indirectly, on tourism as their major source of income. Concerning the importance of tourism and its influence, these two settlements of the region one with the essence of sub-metropolis and the other with a typical setting of a rural milieu with suburb fragrance having their own specialty and uniqueness are selected as research areas for this study. Hoteliers, restaurateurs, travel and tour operators, trekking agents, art/crafts/curios and community households of Baidam catchments and the similar segments in Sarangkot were selected as 
the population universe for this study. The selection of the research zone was not by default but after a deliberate consideration of the heterogeneity of socio-cultural settings with ethnographic significance and the frequency of host-guest contacts and interactions, the sampling areas had been curbed in a frame.

The stratified random sampling technique was used to ensure the equal chance of inclusion in the sample units of each stratum to collect 150 informants from Lake Side and its catchments of Pokhara selecting 25 samples from each respondent's category operating in the study zone (restaurants and bars, travel and tours operators, trekking agents, hotels, art/craft/curios/souvenirs and community households). In case of Sarangkot, a total of 48 respondents were selected using the same technique to configure the size of informants taking 12 from each category - hoteliers (hotel owners), employees working in these hotels in different capacities, non-hotel business owners and villagers. The exploratory research approach supplemented by computer aided SPSS program for the student's t-test based on matched paired observation with substantial support of correlation and standard deviation techniques were used to test the established hypotheses. Besides, the descriptive method was also employed to describe the situation systematically by accumulating the facts, opinions, behaviors or conducts of the host community. The study was mainly based on primary data with minimal backing of the secondary information. Manual processing and analysis was also done for some qualitative data to interpret and construe the qualitative attributes of the information.

\section{ANALYSIS OF VARIABLES}

\section{IMPACT OF TOURISM ON LIVING STYLE}

According to the field survey (2010) based on multiple choice options, it has revealed that tourism has multifaceted implications on the living style of the host community. Some impacts and implications have direct relations with host-guest interface whereas others are due to their own choice of tourism profession. More than 85\% (128 out of 150) respondents of Lakeside, Pokhara perceived that they are leading awfully busy life due to the time they devote for their profession 
(business). Due to their mere busy-ness, $75.33 \%$ people of Lakeside do not get any spare time to meet their relatives, friends and other associates. But the people of Sarangkot, Kaski do not seem as busy as the people of Lakeside. Only about $29.2 \%$ (14 out of 48 ) people agreed that they are devoting more time for their profession / business. This type of circumstance has gradually developed the individualistic behavior in the people of Lakeside as well as Sarangkot. About 17\% people of Sarangkot felt that they are gradually being individualistic due to their engagement in this (tourism related) profession but the figure is about $57 \%$ in case of Lakeside. Almost 25\% people of Sarangkot and $78 \%$ people of Lakeside felt that they are more extravagant now than they were before joining this profession. This type of change in them was, as they felt, due to the increment of income level rather than just due to the meeting and interactions with visitors. But they agreed with certainty that had they not been engaged in this business, they would not have been extravagant. Even $88.67 \%$ people of Lakeside perceived that they like to be more formal and punctual since then their involvement with tourist related activities.

\section{IMPACT OF TOURISM ON DRESSING STYLE (ETHNIC COSTUMES / FASHION)}

The primary purpose of tourism as an industry is economic growth or diversification of the local economy. But the economic prosperity is always accompanied by some other intangible by-products which are basically social and cultural in nature. In some societies, ethical dressing codes and costumes hold very important role for tourism activities. Some visitors may have fascination for unique ethnic attires. When these societies remain in continuous contact with the visitors of different values, norms and dressing style, the host communities dressing code may unknowingly be transformed and a blended attire may crop up gradually loosing the original authenticity. But the viceversa effect may also remain in the visitors. The demonstration effect has the greatest influence on young people and may create generation gaps and class differences, between those who desire change and those who wish to retain traditional ways of life. The dressing code determines the pattern of fashion. Fashion may be defined as permitted range of variation around a norm. Fashion permits and regulates variety and thereby avoids a dull and deadening uniformity. Every human being wants to be like his associates and friends, and sometime different from 
them. Fashion helps to express individuality without going against norms and sanctions that support conformity to fashion in dress are very powerful. Thus, Rao (2002:446) says no woman wants to attend a dinner party in a nightdress. The fashion supported and sanctioned by the society and having adherence to social norms happens to be the dressing code of that particular community. This heritage of dressing codes of any society or ethnic group is likely to be influenced by different factors, and tourism might be one of them.

About $86 \%$ people of Lakeside agreed that tourism influences the dressing style of the local community but only about $33 \%$ people of Sarangkot had similar view in this connection. In both the settlements, most of the respondents expressed that the impact was negative. About $81 \%$ people of the total respondents in Lakeside were aware of the fact that the effect of tourism on the ethnic costumes is negative. Most of the people feel comfortable and relatively modern with the imported dresses. Only $20.83 \%$ people of Sarangkot found the negative effect. Most of the respondents believed that the impact and implications of tourism on the dressing style of both the settlements are moderate. But the number of respondents who found negligible impact of tourism on both the settlements was significantly high $-30.67 \%$ in Lakeside and $43.75 \%$ in Sarangkot. About 21\% and 10\% respondents in Lakeside and Sarangkot respectively sensed the support of tourism to enhance the local and ethnic costumes. They believed that the traditional and indigenous dresses are being revived and fostered only because of tourism. But they also opined that the young generations are highly influenced by the demonstration effect. They rush after the symbols of so-called modernity: sunglasses, shaggy hairs, tattoos, hair raise, piercing (eye-brow/navel/tongue/teats etc.), transparent outfits etc. Unique and interesting ways of life may be pushed aside for western ideals which are not necessarily appropriate for the future of global society.

\section{IMPACT ANALYSIS OVER AGE FACTOR}

There are different types of people who serve the visitors in the destination areas. They are different age-wise too. Most of the people who serve the visitors in the tourism spots are mainly youngsters. The highest numbers of respondents fall under the age group of " 25 - 35 yrs" in both settlements. Some $68.67 \%$ respondents in Lakeside and $62.5 \%$ respondents in Sarangkot agreed that the age group which is 
vulnerable to impact is the group of youngsters. The teen-agers are found very keen to follow the dressing styles of the visitors. According to the respondents, the girls of this age group prefer very short and relatively transparent clothes as tourists do. The multicolored shaggy hair is being a fashion among the girls in this belt. Boys are also not free from this influence. Having long hair and putting on hip-hop dresses are being common in these communities. Nowadays, the tattoo fashion and piercing different parts of the body (ear, nose, eyebrows, tongue, teats and navel) and putting on rings are also increasing enormously in both sexes of this category. Most of them feel modern when they copy and follow the styles of tourists especially of western visitors - is called the demonstration effect in tourism. About $64 \%$ people in Lakeside and almost 52\% in Sarangkot found that the children of this locality are influenced by tourism and tourist related activities.

The respondents have also perceived that the impact of tourism seen over the children is favorable to some extent. They are comparatively smarter, extrovert and feel confident to communicate with any stranger. They have learned several vocabularies of different foreign languages. However, the condition of waifs and strays (Khates) is quite different from this in spite of some favorable observations - learning different vocabularies and being extrovert. The destitute children stroll around until they find tourists. Then they swarm around the tourists begging for money and edible things. The children (and sometimes women too) have become professional beggars who, - often dressed in tattered clothes, dirty, and with forlorn faces - prey upon the sympathies of the tourist passer by who give them chocolate, money and some other edible things that motivate them to inculcate the habit of begging. Begging has become the best modus operandi of some children in this region for their easy living. The informants have also revealed that they (children) sometime engage in some illegal activities like child-prostitution and sale of marijuana/hashish (Ganja) to the specific tourists. The respondents were also found to have a kind of suspicion peep towards the inducement of pedophilia in this belt. Some informants shared their experiences saying that the school-going students of scheduled caste group in Sarangkot area still go for collecting Ganja in the villages to sell to the tourists. The informants also made the fact clear that the 
parents and guardians themselves play the supportive role silently in this matter - perhaps due to the enticement of financial gain. The survey statistics show that the senior citizens are being more open and broad minded on one hand and the feeling of alienation has gradually cropped up in them side by side due to the busy-ness of their young members in tourism related profession/business on the other hand. They find no one even to listen to their emotions and grievances. The sharing and caring in their old age has become the far cry. Whatever is the intensity of this bitterness; this category is found to be the least influenced group in the community due to the development of tourism and tourists related activities.

\section{IMPACT OF TOURISM ON DINING PATTERN}

Food and drink of a country are among its most important cultural expressions. Moreover, the cultural expressions of people are of great interest to most travelers. Ethnographically, Nepal is one of the richest countries in the world. Diverse communities with different feeding habits flourish across the country. Different communities have different styles to begin the day with. The most popular style which has now become the habit of most of the Nepalese people is to wake up with a cup of tea. But this common habit was found only in $25.33 \%$ people of Lakeside. The percentage is higher in case of the people of Sarangkot which is almost $54 \%$. About $75 \%$ people of Lakeside prefer light break-fast in the morning with a cup of tea or coffee. According to the respondents, the break-fast item is sometime omelet or boiled egg or curry-chappati or toast or cornflakes with milk which is not common item of break-fast in the Nepalese societies. They admitted that their menu pattern has been changed due to their involvement in tourism-related activities.

Even the figure is significant in Sarangkot where one can find the complete rural milieu of societal composition. About $45 \%$ people of Sarangkot have similar habit of taking breakfast in the morning. About $40 \%$ people of Lakeside prefer to have brunch - the combined meal of breakfast and lunch taken together. About 11\% people of Sarangkot also have the habit of taking brunch during the mid-day. On asking about the habit of having brunch, the respondents wholeheartedly 
admitted that it is due to their profession, frequent involvement and interaction with tourists they have acquired this habit. Despite this, the null hypothesis for this has been accepted. This implies that the change in menu pattern in this community is not only by tourism. The role of other factors is more than the role of tourism.

\section{IMPACT OF TOURISM ON MENU PRIORITY}

The native food and drink of any country or society carry the cultural identity of that society. Tourists enjoy native foods, particularly items of a local or ethnic nature. Everyone loves trying out local dishes as a part of the fun while traveling. The tourists consider eating and drinking as important aspects of experience of the travel or vacation. Therefore, the purchase of local food and drink by visitors is another source of revenue - popularly known as tourists' revenue. Restaurants and hotels can provide unique and favorable impressions on the tourist if they feature local dishes perhaps with an explanation on the menu about what the dish consists of and how it is prepared. Sometimes the type, setting and atmosphere of restaurants can complement the type of food being served. How these foods and drinks are prepared and presented are of great importance. Among the happiest memories may be the experience of dining in a particularly attractive or unusual eating place where local foods were prepared and served. The most interesting part of the Nepali dal-bhat-tarkari is the portion (recipe) to be mixed while eating. The right combination of dal (pulse gravy), bhat (rice), tarkari (curry) and achar (pickles) determines the delicacy of the meal. Only achar or dal is not eaten separately. Therefore, the gastronomy of Nepalese cuisine not only requires appropriate recipe while cooking but also requires adequate technique while eating.

In spite of its eminence peculiarity, only about $62 \%$ people of Lakeside have given first priority to the Nepalese cuisine. About $18.67 \%$ people emphasized oriental (Chinese, Japanese, Thai etc.) menu as their first choice. Almost 8\% people put Continental menu in the list of their first priority. Out of the total respondents of Lakeside, about $7 \%$ people selected the American menu as their first priority. The amazing fact regarding the menu-choice is that almost 50\% informants selected the Indian cuisine as their second best choice, about $37 \%$ people put the oriental menu in the third rank, and around $46 \%$ people chose the continental cuisine in the fourth rank. The fact clearly reveals that the dining habit of the people of Lakeside has been changing slowly and the 
craze towards the foreign food is growing gradually among the people of Lakeside. Similar effect can be seen among the people of Sarangkot as well. Sarangkot in itself is a village with a complete vibes of rural set up. However, only $83.33 \%$ respondents selected Nepali food as their first priority whereas $16.67 \%$ people put it in the list of second choice. About 48\% people liked the Indian menu as their second choice whereas $47.91 \%$ people chose the continental menu as their third preference. About 32\% people liked to put the oriental menu in the second rank of their priority list where as $10.41 \%$ people put American menu in the third rank. This figure reveals that the influence of tourism over the dining preference of the people of Sarangkot is also significantly high considering its geographical and societal configuration.

\section{IMPACT OF TOURISM ON OUTING FOR LUNCH/DINNER}

Tourism is an agent of change and development. Social contact between residents and tourists can be exciting as well as refreshing. Tourism can inhibit its far reaching impacts in the people of the destination settlements. Almost 51\% people of Lakeside prefer to have their lunch in the restaurant away from their usual place at least two times a week. Similarly $12.67 \%$ people expressed that they have their lunch at least four times a week in restaurants. Around 51\% people like to have their meal outside their home in the evening at least once a week. The figure is significant in case of Sarangkot too. Almost $31 \%$ and $12.5 \%$ people like to have their meal outside their home at least once a week in the evening and in the morning respectively. This unveils the fact that the people of these two destinations have gradually imbibed the habit of going out for dining from their usual refectory of their home.

\section{IMPACT OF TOURISM ON MERRY-MAKING AND LEISURE ACTIVITIES}

Tourism stimulates fresh vigor in the society in terms of the broader outlook which is not only desirable but also necessary to improve the quality life of people in particular, and the society in general, which can look for knowledge, awareness, etc. from tourism. Tourism has many faces and so has the society. Each face or unit of the society has a complete set of culture maintaining its own value system, beliefs, ideas, attitudes, perceptions and habits. The people of every society may have their own approach of entertainment, merry-making and utilizing the leisure time. Almost $31 \%$ people of Lakeside would like 
to go to the pubs and discotheques to entertain where they dance and relax with liquor especially in the evening. But the number of female respondents having the same mind-set in this connection is negligible. Similarly, $4.16 \%$ from Sarangkot feel comfortable to step into the disco and dance restaurants for recreational purpose. Rather, $12.5 \%$ people of Sarangkot would like to go for short hike in free time rather than to visit pubs and discotheques. Out of the blue, only $13.33 \%$ respondents in Lakeside supported this option. The research divulges that most of the people of Lakeside $(63.33 \%)$ are very cognizant and inquisitive to know and learn about tourism. They like to read tourism-related magazines, journals and newspapers in their free time. Almost one fourth of the respondents in Sarangkot had the same consideration. Though they find abnormal free time during the plummet period, they become rather busy during the high seasons. They dedicate the time entirely for the business/profession. So, when they get free time in slack period, $49.33 \%$ people of Lakeside like to go to meet their friends and relatives to strengthen the relationship which they think very supportive and functional to promote their business. The null hypothesis has been accepted in this case indicating that the merry-making and the utilization of leisure time may not markedly be influenced by tourism.

\section{INFLUENCE OF TOURISM ON TRADITIONAL PROFESSION OF INDIGENOUS PEOPLE}

Where economic objectives of tourism have been placed before community concerns as prime targets, it is also important to be aware of some of the wider corollaries and ramifications of tourism development. Snowballing effects of tourism are very difficult to ascribe and assess. A significant number of respondents in Lakeside (79.33\%) and Sarangkot $(64.58 \%)$ agreed that tourism is the only means of bread and butter for the members of these indigenous families. The displacement of local communities to make way for tourism is one of the most significant focal points of debates over recent years. Tourism has also caused governments to act in ways which contravene the rights of local people. About $74 \%$ people of Lakeside expressed that the indigenous local families of Damai and Majhi have been displaced from this locality only due to the development of tourism in the Fewa Lake catchment areas. The development of tourism in these catchments eventually obligated them to be displaced from their ancestral land. Nonetheless, this type of impact is not visible in Sarangkot region so far. The significant negative implication of tourism in long range is dependency. About 
$87 \%$ people of Lakeside left their traditional profession and completely merged into tourism for their living. The rate in this regard can be said exceptionally high for Sarangkot $(70.83 \%)$ when compared in tourism development aspects. People living in these societies are gradually being parasitical masses loosing their professional identity and selfreliantness little by little. The indigenous people are slowly but steadily sending-off their traditional ancestral profession. Almost $65 \%$ people of Sarangkot and $58 \%$ people of Lakeside perceived it so.

\section{IMPACT OF TOURISM ON RELATIONSHIP MODE}

The growth of tourism may produce both problems and opportunities on the vast scale for societies, and its impact might be economic, socio-cultural, environmental and political. As per the respondents' expression, tourism does have implications on social relations as well. About $73.33 \%$ respondents of Lakeside and $54.17 \%$ of Sarangkot strongly supported that tourism depersonalizes the relationship emphasizing only on the commercial relations. Some of them $(45.33 \%$ - Lakeside and 10.42\% - Sarangkot) also viewed that tourism develops the individualistic behavior among the people of the host community. About 44\% people of Lakeside supported that tourism enfeebles the social cohesion and weakens the traditional social fabric. Some of the respondents did perceive some positive implications of tourism. About $40 \%$ people of Lakeside and 35\% people of Sarangkot opined that tourism has reduced the community conflict enhancing the communal feelings in their society. Some of the respondents (11.33\%) in Lakeside also perceived that the development of tourism in this society has made the social bond stronger than before.

\section{IMPACT OF TOURISM ON SOCIAL/FAMILY STRUCTURE}

The research shows that the effects of tourism can be measured in various social issues. Almost 64\% informants of Lakeside kept hold of the assessment that tourism weakens the traditional family structures. Tourism has developed more individualistic behavior among the people of this community which will eventually drive people towards the nuclear family. According to them, this trend is already prevalent in this community. Nevertheless, this type of observation is very low $(8.33 \%)$ among the people of Sarangkot. The notable expression made by the 
respondents ( $88.67 \%$ - Lakeside and $47.91 \%$ - Sarangkot) is that the tourism has eliminated the feeling of caste-ism in these communities. The other highly visible influence of tourism on the indigenous communities is the increase marital relationship with visitors; 44.67 $\%$ respondents in Lakeside and $60.41 \%$ respondents in Sarangkot have supported this comment. Some other negative impacts of tourism on indigenous society are weakening the social cooperation, being materialistic, more money oriented, feeling of inferiority complex, etc.

\section{TEST OF HYPOTHESES}

The following ten null hypotheses were tested in this research work. Null hypotheses $\left(\mathrm{H}_{\mathrm{o}}\right)$ were rejected when the obtained value of t-test $\left(\mathrm{t}_{\mathrm{o}}\right)$ exceeded the table value $\left(\mathrm{t}_{\mathrm{v}}\right)$ at $5 \%$ level of significance and the other way round for the acceptance of them.

$H_{o}$ : There is no significant relationship between the tourist-host interface and the living style of the host population.

$H_{o}$ : There is no significant relationship between the tourist-host interface and the dressing style of the host population.

$H_{o}$ : There is no significant relationship between the tourist-host interface and the cuisine priority of the host population.

$H_{0}$ : There is no significant relationship between the tourist-host interface and the dining pattern of the host population.

$H_{0}$ : There is no significant relationship between the tourist-host interface and the impact on age factor of the host population.

$H_{o}$ : There is no significant relationship between the tourist-host interface and the outing of the host population.

$H_{0}$ : There is no significant relationship between the tourist-host interface and the merrymaking and leisure activities of the host population.

$H_{o}$ : There is no significant relationship between the tourist-host interface and the traditional profession of the indigenous population of the host community.

$H_{o}$ : There is no significant relationship between the tourist-host interface and the social relation of the host population.

$H_{o}$ : There is no significant relationship between the tourist-host interface and the family structure of the host population.

In this study, lifestyle of the host people is disintegrated into some specific components. These components are manifested in living style, 
dressing style (fashion), dinning pattern, menu (cuisine) priority, outing for lunch /dinner, merry-making and leisure activities, social relation and social structure of indigenous people. Every individual component was tested by using the student's t-test thereby equally considering the values of standard deviation $(\sigma)$ and correlation coefficient $(r)$. The values and conclusions derived are as follows:

\begin{tabular}{|c|c|c|}
\hline Framework of Test for Lifestyles & $\begin{array}{l}\text { Table value of } \\
\text { t-distribution } \\
\text { at } 5 \% \text { level of } \\
\text { significance }\end{array}$ & Concluding remarks \\
\hline 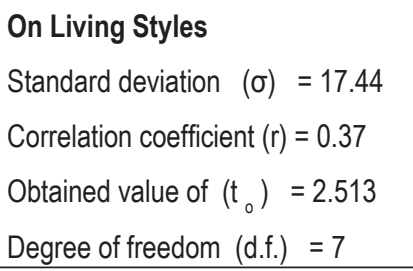 & $t_{v}=2.365$ & $\begin{array}{c}t_{0} 2.513>t_{v} 2.365 \\
\text { Null Hypothesis - rejected } \\
\text { Alternative hypothesis - accepted }\end{array}$ \\
\hline $\begin{array}{l}\text { Dressing Styles (Fashion) } \\
\text { Standard deviation }(\sigma)=10.62 \\
\text { Correlation coefficient }(r)=0.115 \\
\text { Obtained value of }\left(t_{0}\right)=2.884 \\
\text { Degree of freedom }(\text { d.f. })=5\end{array}$ & $t_{v}=2.571$ & $\begin{array}{c}t_{0} 2.884>t_{v} 2.571 \\
\text { Null Hypothesis - rejected } \\
\text { Alternative hypothesis - accepted }\end{array}$ \\
\hline $\begin{array}{l}\text { Age-wise Impact } \\
\text { Standard deviation }(\sigma)=10.02 \\
\text { Correlation coefficient }(r)=0.962 \\
\text { Obtained value of }\left(t_{0}\right)=5.303 \\
\text { Degree of freedom }(\text { d.f. })=2\end{array}$ & $t_{v}=4.303$ & $\begin{array}{c}t_{0} 5.303>t_{v} 4.303 \\
\text { Null Hypothesis - rejected } \\
\text { Alternative hypothesis - accepted }\end{array}$ \\
\hline $\begin{array}{l}\text { On Dinning Pattern } \\
\text { Standard deviation }(\sigma)=8.88 \\
\text { Correlation coefficient }(r)=0.653 \\
\text { Obtained value of }\left(t_{0}\right)=1.864 \\
\text { Degree of freedom }(\text { d.f. })=4\end{array}$ & $t_{v}=2.776$ & $\begin{array}{c}t_{0} 1.864<t_{v} 2.776 \\
\text { Null Hypothesis - accepted } \\
\text { Means no significant difference in } \\
\text { the dinning pattern }\end{array}$ \\
\hline $\begin{array}{l}\text { Cuisine (menu) Priority } \\
\text { Standard deviation }(\sigma)=5.76 \\
\text { Correlation coefficient }(r)=0.874 \\
\text { Obtained value of }\left(t_{0}\right)=5.615 \\
\text { Degree of freedom (d.f.) }=35\end{array}$ & $t_{v}=1.960$ & $\begin{array}{l}\qquad t_{0} 5.615>t_{v} 1.960 \\
\text { Null Hypothesis - rejected } \\
\text { High acceptance of alternative } \\
\text { hypothesis }\end{array}$ \\
\hline
\end{tabular}


Tourism and Lifestyle...... Sharma

\begin{tabular}{|c|c|c|}
\hline $\begin{array}{l}\text { Outing for Lunch/Dinner } \\
\text { Standard deviation }(\sigma)=6.59 \\
\text { Correlation coefficient }(r)=0.561 \\
\text { Obtained value of }\left(t_{0}\right)=2.807 \\
\text { Degree of freedom }(\text { d.f. })=15\end{array}$ & $t_{v}=2.731$ & $\begin{array}{c}\mathrm{t}_{\mathrm{o}} 2.807>\mathrm{t}_{\mathrm{v}} 2.731 \\
\text { Null Hypothesis }- \text { rejected } \\
\text { Alternative hypothesis - accepted }\end{array}$ \\
\hline $\begin{array}{l}\text { On Merrymaking and Leisure } \\
\text { Standard deviation }(\sigma)=14.23 \\
\text { Correlation coefficient }(r)=-0.139 \\
\text { Obtained value of }\left(t_{0}\right)=2.284 \\
\text { Degree of freedom }(\text { d.f. })=6\end{array}$ & $t_{v}=2.447$ & $\begin{array}{l}\qquad t_{0} 2.284<t_{v} 2.447 \\
\text { Null Hypothesis - accepted } \\
\text { Means the changes perceived by } \\
\text { host people might have caused by } \\
\text { other factors like globalization }\end{array}$ \\
\hline $\begin{array}{l}\text { On Profession of Indigenous } \\
\text { People } \\
\text { Standard deviation }(\sigma)=11.35 \\
\text { Correlation coefficient }(r)=0.708 \\
\text { Obtained value of }\left(t_{0}\right)=5.105 \\
\text { Degree of freedom }(\text { d.f. })=12\end{array}$ & $t_{v}=2.179$ & $\begin{array}{c}t_{0} 5.105>t_{v} 2.179 \\
\text { Null Hypothesis }- \text { rejected } \\
\text { High acceptance of alt. hypothesis }\end{array}$ \\
\hline $\begin{array}{l}\text { On Social Relation } \\
\text { Standard deviation }(\sigma)=10.64 \\
\text { Correlation coefficient }(r)=0.766 \\
\text { Obtained value of }\left(t_{0}\right)=4.117 \\
\text { Degree of freedom }(\text { d.f. })=4\end{array}$ & $t_{v}=2.776$ & $\begin{array}{c}t_{0} 4.117>t_{v} 2.776 \\
\text { Null Hypothesis }- \text { rejected } \\
\text { High acceptance of alt. hypothesis }\end{array}$ \\
\hline $\begin{array}{l}\text { On Social Structure } \\
\text { Standard deviation }(\sigma)=14.62 \\
\text { Correlation coefficient }(r)=0.731 \\
\text { Obtained value of }\left(t_{0}\right)=2.515 \\
\text { Degree of freedom }(\text { d.f. })=7\end{array}$ & $t_{v}=2.365$ & $\begin{array}{c}t_{0} 2.515>t_{v} 2.365 \\
\text { Null Hypothesis }- \text { rejected } \\
\text { High acceptance of alt. hypothesis }\end{array}$ \\
\hline
\end{tabular}

There were altogether ten tests under this category. The results of only two tests (dinning pattern and merry-making/leisure) are in favor of null hypothesis. Considering this fact, the post-results informal interviews and conversations were organized in this connection. The qualitative information obtained thereafter in case of dinning pattern and merrymaking/leisure activities were completely against the results despite the statistical figures. The results of remaining tests (eight out of ten) completely decline the null hypothesis accepting the fact that lifestyles of the people of Lakeside and Sarangkot have significantly influenced by the development of tourism. 
Tourism in Nepal is a lately entered prospective player of national economy. The government of Nepal has also admitted it as a high value industry. This smoke-less export industry is the only industry in Nepal with the core competitive advantage to earn foreign exchange. Whatsoever, its negative implications in host societies cannot be underrated. This research was mainly based on the analysis of the impacts and implications of tourism over the lifestyles of host population when two different and distinct cultural values of tourists and hosts interface each other via tourism. Ten variables of lifestyle were taken for observation and were investigated with the help of students' t-test in conjunction with correlation and standard deviation. The research findings reveal that the lifestyle of host population is highly influenced by host-tourists interactions and interfaces. Tourism, though generally an economic enterprise, is a complex mélange of the multiple interconnected frontages of human issues. It appears in an anthology of forms and facets in the society - some latent and some visible, some positive and some negative. The fact is that tourists not only bring money to the destination; they also carry an explicitly visible and demonstrating life-style along with them. Their outfits, food habits and entertaining style all bring some novelty and distinctiveness to the area of their visit. Human instinct drives the people of host communities to adopt new styles and habits from strangers even just for the taste sake. Furthermore, social and cross-cultural interactions have been the intrinsic motivational aspects for many people in the travel process.

The study has revealed that the influence of imitation on local people by observing the life style of tourists - called demonstration effect- is more visible and perceptible in Lakeside than in Sarangkot catchments. Youngsters are seen highly influenced from tourism followed by children of the both communities. Senior citizens are amongst the least influenced category. The people of Lakeside noticeably find some changes in their dining habits too. Some people have habit of taking brunch. Continental, American and Oriental cuisines are getting popularity in these destinations. More than half of the respondents of Lakeside prefer to have their lunch in the restaurant away from their usual place at least two times a week. The figure is significant in case of Sarangkot too. This unveils the fact that the people of these two destinations have gradually imbibed the habit of going out for dining from their usual refectory of their home. 
Some people of Lakeside would like to go to the pubs and discotheques to entertain in the leisure time where they dance and relax with liquor especially in the evening. However, the number of female respondents having the same mind-set in this connection is negligible. Some of them would like to have a short hike in their free time too. The repercussions of tourism on social as well as individual behavior are slow but penetrating and lasting. It infuses a large number of small effects in a bowl. They individually appear to be almost insignificant but together appear with synergic bang. As per the perception of the respondents, tourism has imprinted individualistic behavior among the people of Lakeside which will eventually drive people towards the nuclear family. But this effect is not in flash in Sarangkot yet. The development of tourism has influenced the local people over their attitudes too. According to them, tourism has escorted them to be more open, tolerant, hospitable, co-operative and a bit extravagant than before. Tourism changes the living style of the host community. People of the host community become busy even in the great festivals like Dashain and Tihar. They don't get any time to meet their parents, relatives and friends. As a result the knots of the social fabric are being gradually weaker in Lakeside area. But this kind of influence is very less in case of Sarangkot. A significant number of respondents agreed that tourism is the only means of bread and butter in both areas. People living in these societies are gradually being parasitical masses loosing their professional identity and self-reliantness little by little. The indigenous people are slowly but steadily sending-off their traditional ancestral profession. All these socio-cultural impacts and impressions are relatively more visible and apparent in Lakeside than in Sarangkot. This implies that the pace of tourism development, frequency of hostguest interactions and interfaces along with the dissimilarity of hostguest culture are the major causative players of social as well as cultural diffusion, infusion, acculturation and assimilation in host populations.

\section{REFERENCES}

Bottomore, T. B. (1986). Sociology: A Guide to Problems and Literature.

New Delhi: S. Chand and Company Ltd.

Fridgen, J. D. (1996). Dimensions of Tourism. USA: Educational Institutite, American Hotel and Motel Association.

Ghosh, B. (2002). Tourism and Travel Management. New Delhi: Vikash Publishing House Pvt. Ltd. 
Goeldner, C. R., Ritchie, J. R., and McIntosh, R. W. (2000). Tourism: Principles, Practices, Philosophies. New York: John Wiley and Sons, Inc.

Gupta, S. P. (1992). Statistical Methods. New Delhi: Sultan Chand and Sons Puplishers.

Kothari, C. R. (2002). RESEARCH METHODOLOGY Methods and Techniques. New Delhi: Wishwa Prakashan.

Mathieson, A., and Wall, G. (1982). Tourism: Economic, Physical and Social Impacts. UK: Longman.

Rao, C. N. (2002). Sociology: Primary Principles. New Delhi: S. Chand and Company Ltd.

Reisinger, Y., and Turner, W. L. (2004). Cross-Cultural Behaviour in Tourism: Concepts and Analysis. UK: Elsevier Butterworth-Heinemann.

Ritzer, G. (1992). Sociological Theory. New Delhi: McGraw Hill Company Inc.

Sharma, R. (2005). Socio-cultural Impacts of Tourism on Host Community: A Case of Pokhara and Its Vicinity. MA Dissertation, Departmentt of Sociology/Anthropology, P.N. Campus, T.U., Pokhara, Nepal.

Sharma, R. (2008). "Tourism and Peace: A Study of Cleavage between Quotes and Reality." In Janapragyamanch. Vol.9. pp 5462.

Sharma, R. (2008). "Tourism and Value System: An Impact Assessment from Socio-cultural Perspective." In Himalayan Journal of Sociology and Anthropology. Vol. III, pp. 106-225.

Theobald, W. F. (Ed.). (2001). Global Tourism. UK: ButterworthHeinemann. 